\title{
LEGAL CHARACTERISTIC OF THE FRANCHISE AGREEMENT IN GERMANY
}

\author{
Tsahik Kolinko', Krystyna Rezvorovych ${ }^{2}$, Maryna Yunina ${ }^{3}$
}

\begin{abstract}
The purpose of the article is to study the legal nature of the franchise agreement in Germany. The research subject is the franchise agreement in Germany. The methodology of research. The study is based on the use of general scientific and special scientific methods and techniques of scientific cognition. The dialectical method allowed studying the definition of franchising agreement in Germany and its essentials. The comparative legal method was applied in order to compare doctrinal approaches to this issue. Interpretation of the content of laws and regulations of German legislation covering issues related to the conclusion of the franchising agreement in this country was carried out by means of the normative-dogmatic method. The system-structural method was used to study franchising agreement in Germany as a unitary whole (system) with coordinated functioning of all its elements. Methods of grouping and classification formed the basis for singling out a list of requirements needed to conclude franchising agreement in Germany, as well as provision to be included in this agreement. Methods of analysis and synthesis helped to investigate separate parts of such an agreement in order to formulate further conclusions. Practical implications. The positive experience of Germany in the regulation of issues related to the conclusion of the franchising agreement can be used for introducing corresponding changes in the legislation of Ukraine. Value/ originality. This scientific paper is the first study in Ukraine devoted not to general issues of regulation of franchising activity in Europe but specifically to franchising agreement in a separate country (in Germany).
\end{abstract}

Key words: franchising, franchising agreement, franchiser, franchise, disclosure, essentials.

JEL Classification: K12, F55

\section{Introduction}

Franchising is one of the types of business activity, which allows earning extraordinary profits and achieving fast growth without significant investment or a broad managerial infrastructure. In such diverse spheres as food, trade, education, healthcare, financial services, etc., franchising is the most popular "catalyst" for international business and makes a significant contribution to world trade. Governments from different countries are turning to franchise as an effective strategy for welfare since social franchising is a reliable way to solve major social problems.

Given the positive role that franchising can play in the global economy, it is important to understand how the regulation of this institution in different countries of the world takes place. As the franchise market in Germany is well-formed and one of the most regulated, in this article we will turn to the experience of this particular state and analyse the features inherent in the franchising agreement, as well as the legislative acts that regulate this issue.

The research of franchising as a type of international business was conducted by N. V. Bezrukova, L. V. Voroniak, T. M. Hryhorenko, N. M. Hrushchynska,

\footnotetext{
Corresponding author:

${ }^{1}$ Dnipropetrovsk State University of Internal Affairs, Ukraine.

${ }^{2}$ Dnipropetrovsk State University of Internal Affairs, Ukraine.

${ }^{3}$ Dnipropetrovsk State University of Internal Affairs, Ukraine.
}

O. M. Kolodiziev, O. Ye. Kuzmin, A. M. Mahomedova, V. Ye. Sakharov, V. S. Tatarinov, T. M. Tsyhankova, A. V. Tsyrat, I. M. Shkola and others. However, it is the first study in Ukraine that is devoted to franchising in Germany and, in particular, the legal characteristics of a franchising agreement in this country.

In connection with the course of Ukraine on European integration, it seems expedient to study the positive experience of the leading European countries for its further implementation in the legislation of our state. Therefore, the purpose of this article is to study the legal nature of franchise agreement in Germany a state that has a fully formed franchise market, which has been achieved over a relatively short period of time.

\section{Presentation of the main material}

In Germany, franchising originated in the late 60 s of the last century, when the local trade networks Nordsee (fish sandwiches to go), Ihr Platz (pharmacy), and OBI (do-it-yourself stores) began to use franchising to reach rapid growth. Due to this, from 1975 to 1985 , the number of franchise companies increased from 40 to 
200. However, franchising reached the real prosperity in the early 90s after the reunification of the FRG and GDR, when the people of East Germany in search of work began to massively employ a franchise business (Marzheuser-Wood, 2014).

During the last decade, franchising in Germany has been developing at a rapid pace. Thus, from 2007 to 2017 , the total number of franchise companies increased from 630 to more than 1000. During the same period, the total number of employees in this area increased from 250 thousand to 700 thousand. The growth rates of the annual turnover of franchise companies in Germany are promising. If in 2007 the annual turnover in the field of franchising was about 40 billion euros, then in 2017, it was estimated at about 99.2 billion euros, that is, it increased by more than $100 \%$ over 10 years. The three largest sectors of franchise activity are service provision (39\%), retail trade (31\%), hotels and gastronomy (20\%) (Statistiken zum Thema Franchise).

On the territory of this country, there are a large number of both domestic and foreign franchise networks. National franchise networks such as ApolloOptik, Arko Kaffee und Confiserie, and BabyOne are located next to such giants as McDonald's, Hertz, Intercontinental Hotels, Domino's Pizza, Burger King, and Mailboxes. Each year Impulse conducts research and selects the top ten German franchise networks, which later rewards valuable prizes.

The German Franchise Association is an important authority in this segment. The German Franchise Association is a member of the European Franchise Federation and the World Franchise Council. This organization regularly conducts relevant research, publishes statistics and recommendations.

Despite the fact that the German Franchise Association (hereinafter referred to as the Association) is a nongovernmental body and its membership is not binding, the principles contained in the Association's Code of Ethics, adopted in accordance with the European Code of Ethics for Franchising, have a certain effect on the legal relationship in this field. This is due to the fact that the Association is a union of franchise companies, for which it establishes mandatory rules of conduct and verifies whether strict membership requirements have been observed when joining the Association. Considering that membership in the Association is considered a sign of the quality and authority of the franchisor, they all adhere to the guidelines to become (and remain) members of the Association.

There is no legal definition of franchising in Germany. When considering the relevant category of cases, German courts use the definition given in Clause 1 of the European Code of Ethics for Franchising (European Code of Ethics for franchising) (hereinafter referred to as the Code of Ethics) adopted by the European Franchise Federation, to which the country under consideration belongs. According to this definition, franchising is a system for the sale of goods and/or services and/or technologies based on close and constant cooperation between legally and financially independent enterprises, a franchisor and a franchisee, within which the franchisor provides franchisee with the right and entrusts with responsibility to carry out business activity in accordance with the concept of franchisor. The franchisee, in exchange for direct or indirect financial remuneration, has the right to use the franchisor's trade name and/or trademark, know-how, business and technical methods of activities, procedural system, and other intellectual property rights, using ongoing commercial and technical assistance within the framework and for a period of validity of a written franchising agreement concluded between the parties for this purpose.

As can be seen from this definition, the parties to the franchise agreement are franchisor and franchisee. The law does not impose any restrictions on the business form of the franchisor, however, its most common form in Germany is a limited liability company $(\mathrm{GmbH})$ because it requires a minimum investment amount (at least 25,000 euros) and guarantees limited liability to creditors (within the framework of investments). Other common forms of franchise companies are joint-stock company (AG) (minimum share capital - 50,000 thousand euros) and a newly introduced entrepreneurial company with limited liability (Unternehmergesellschaft (haftungsbeschränkt)), which to a certain extent, is similar to a limited liability company $(\mathrm{GmbH})$ and is popular due to the lack of a requirement for a minimum amount of capital (Metzlaff, Billing, 2011).

In Germany, there is no special law on franchising, but this issue is fully regulated. Thus, the rules governing the implementation of franchising activities are contained, in particular, in: the general principle of culpa in contrahendo (the principle of pre-contractual liability in civil law), due to which a pre-contractual obligation to information disclosure was created; laws that provide for liability for misleading the person; agency law, including the provisions on reimbursement; Commercial Code of Germany (hereinafter referred to as the German CC), in particular, in the principle of integrity, which is enshrined in this legal act; in the rule that agreements that violate the requirements of morality are invalid, as well as in the provision that in the presence of serious circumstances, the effect of long-term agreements may be terminated.

In accordance with German law, the parties must act honestly and fairly when entering into business relations. This requirement also includes obligations to voluntarily disclose information based on the principle of culpa in contrahendo, provided for in Part 2 of Art. 311 of the German CC (Bürgerliches Gesetzbuch). When negotiating a franchising agreement, both parties must provide true information, not mislead one another and not make false promises, but they do not have the right to disclose material information. This is especially true for data that can significantly affect the success of the 
transaction (performance of other franchisees, financial risks, etc.) and encourage the potential franchisee to become a part of the network. The franchisee's consent to the franchise must be based on reliable and verified data, so if the franchisor or his representatives provide false information, they will be liable in accordance with Part 3 of Art. 311 of the German CC.

That is why a franchisor who wants to place his business in Germany should be very careful because any noncompliance with the principle of culpa in contrahendo will mean that the agreement can be declared invalid. In the event of a breach of the above requirement, the franchisor must also return the franchisee to the state, in which the latter would be if the franchisor fulfilled his obligation to disclose information. This means that the unscrupulous franchisor must repay the funds received for the sale of the franchise, as well as to indemnify the franchisee all losses incurred in connection with the transaction. The law establishes a limitation period of three years for claims for recognition of a franchising agreement invalid. Its course begins with the moment when the franchisee has learned about the circumstances that may be the basis for filing a statement of claim in court.

Although it is not legally defined, which information should be disclosed when negotiating a contract, you can learn about it by referring to German Case Law and the Code of Ethics. Consequently, when entering into an agreement, data should be provided on: 1) the concept of franchising; 2) the initial and permanent provisioning provided by the franchisor; 3 ) the date of the establishment of the franchise network; 4) availability of "pilot" (trial) version of franchising activity; 5) the availability of the necessary capital and labour force for conducting franchising activities; 6) accurate information on the profitability of franchising activities; 7) the actual number of franchisees; 8 ) the number of pending court cases that may affect the activities of potential franchisees (Part 3 of the Code of Ethics).

Information must be provided within a reasonable time before the conclusion of the franchising agreement. At the same time, the provision on the need for disclosure of data should not affect the conclusion of a preliminary agreement, if the parties have agreed on its conclusion. Since the duration of such an agreement is rather short, it does not entail significant economic consequences and does not bind directly to conclude a franchising agreement.

At the legislative level, it is not prescribed in which form the necessary data is provided. However, the German Franchise Association recommends providing them in writing. The written form is also provided for by the German Case Law and the Code of Ethics (Clause 3.4). German lawyers who specialize in this field have even developed special templates with the necessary list of issues to ensure full disclosure.

In addition, in Clause 2.2 of the Code of Ethics, additional requirements are imposed on the franchisor, which he must perform before concluding a franchise agreement. They are as follows: 1) the franchisor must successfully engage in business over a period of time and run at least one pilot project before establishing his own franchise network; 2) the franchisor must be the owner or legal user of the company name, its trademark or any other special designation of the network; 3) the franchisor must undertake initial training for the franchisee, as well as provide him with ongoing commercial or technical support throughout the contract.

In turn, the franchisee is obliged: 1) to make maximum efforts to develop the franchise network, to maintain its authenticity and reputation; 2) provide the franchisor with accurate data for verifying the effectiveness of doing business and compiling the financial statements necessary for the effective management of the franchise network; 3) provide the franchisor and/or his representatives with permanent access to the premises of the franchisor and provide necessary data at the franchisor's request within reasonable timelimits; 4) not disclose to third parties the information on the know-how provided by the franchisor, either during the period of validity of the agreement or after its termination (Clause 2.3 of the Code of Ethics).

Civil law does not provide for essential terms and conditions of a franchising agreement, which allows the parties to agree on their own discretion. Restrictions on the application of certain provisions of the franchising agreement are an exception and mainly derive from antimonopoly legislation and laws relating to the terms of standardized agreements.

Nevertheless, Clause 5.4 of the Code of Ethics contains a list of conditions that it is desirable to include in franchising agreement. They are as follows: 1) the rights and obligations of the franchisor and franchisee; 2) the goods and services provided by the franchisor, as well as the transfer of know-how; 3) franchise fee; 4) the procedure for the use of intellectual property rights; 5) duration of agreement: it should be enough for the franchisee to be able to return the initial investment (usually a franchising agreement is concluded for 10 years); 6) the conditions under which the contract may be terminated or renewed; 7) the conditions under which a franchisee can sell franchise business; 8) the franchisor's right to develop this franchise network; 9) the provision for the immediate return of the franchisor's property in the event of termination of the agreement and, if necessary, payment of compensation to the franchisee; 10) control right: the franchisee should receive recommendations on the limits of compliance with the concept of franchising activities; 11) sanctions for breach of a contract.

Art. 242 of the German CC states that the parties to the agreement act in accordance with the principle of integrity. This is the basic principle of German law and the general provision, which allows the court to adapt its decision to the circumstances of a particular case. 
The realization of this principle consists in assessing the terms of the agreement in terms of their reasonableness in accordance with the requirements of Art. 307 of the German CC. The principle of integrity requires that the terms of the agreement are honest. The decision as to whether a particular behaviour violates this fundamental principle depends on the circumstances of each individual case.

Art. 305 of the German CC, entitled "General conditions for the conclusion of agreements", applies to a franchise agreement insofar as one party joins the terms of the agreement, established by the other party (Part 2, Article 305). The terms of the agreement must meet the criteria of reasonableness and fairness and should not place one of its parties in an extremely unfavourable position with respect to another, which violates the requirement of integrity. Otherwise, these provisions are invalidated and cancelled. For example, a franchisee who is not a limited liability company has the right to cancel the agreement within 14 days from the moment of its conclusion, if it contains an obligation to take delivery from the franchisor more than once, while the total amount of the franchisee's contribution to the newly created company does not exceed 75 thousand euros (Franchise 2019).

The regulation of issues related to the conclusion of a franchise agreement is also governed by the Unfair Contract Terms Act (UCTA), adopted in 1977 by the United Kingdom Parliament (Unfair Contract Terms Act 1977). In accordance with this Law, any provision of the model agreement, which has not been discussed by its parties, is subject to verification of equity. If such a provision can cause infliction of loss to the franchisee, the franchisor is required to justify the need for it to be included in the agreement. In addition, according to the UCTA, the franchisee has the same security guarantees as the buyer.

However, it should be noted that the UCTA is not an act binding on the international level. If the franchisor is registered in another country, the law can be applied that acts in its territory. However, in Germany, when concluding a franchising agreement, the UCTA is used almost always.

Since the franchising agreement in Germany does not require state registration, it is considered concluded from the moment when the parties have reached agreement on all terms. Compliance with the written form of this agreement is mandatory.

Further legal relations between the franchisor and the franchisee, if the franchisee undertakes to continue to purchase the goods and equipment from the franchisor, are regulated mainly by the agency law, as well as by the antimonopoly law. As the German antimonopoly legislation was fully aligned with the EU provisions in 2005, issues such as restriction of competition, price control, conducting procurement, and determining the territory of the agreement are currently regulated by the European Competition Law. According to Art. 101 of the Treaty on the Functioning of the European Union (TFEU)
(Treaty on the Functioning of the European Union), it is prohibited to conclude such agreements between enterprises that may affect trade between member states of the EU and which are aimed at preventing, restricting or distorting competition in the pan-European market.

The validity of the franchising agreement is not legally binding, as the parties, as already noted, are free to agree on the terms of the contract. However, the provisions of the contract that the term of its action is, for example, 40 years, can be abolished in view of the illegal restriction of franchisee's business freedom. On the other hand, the condition for a too short term of the agreement (1 year) can also be considered invalid, because for such a period of time the franchisee will not be able to establish such franchise activities as to fully recover all funds invested in the purchase of a franchise.

At the same time, there are certain timeframes for the purchase of goods and equipment from the franchisor. Thus, in a franchising agreement, it is often prescribed that the franchisee is obliged to buy goods only from the franchisor and no one else, including other franchisees. Such a franchise obligation is legitimate only if it does not violate the rules of competition law and is necessary to maintain the authenticity and reputation of the franchise network. If such an obligation is not necessary to maintain the authenticity and reputation of the franchise network, then the Block Exemption Regulation (BER), adopted in accordance with Art. 101 (3) of the Treaty on the Functioning of the European Union (Commission Regulation). According to Art. 5 of this Regulation, the procurement obligation is not subject to its regulation, if its term does not exceed five years. If the term of the obligation exceeds five years or is automatically prolonged then the provisions prescribed in the BER are applied.

As a rule, a franchising agreement is terminated due to the expiration of its validity, receiving notice of its termination or concluding an agreement to abolish franchise relations. However, there may be circumstances that lead to sudden contradictions between the franchisor and the franchisee, as a result of which one party may wish to terminate the franchise agreement even without prior notice. According to German law, termination of the contract without notice is possible only when there is a good reason for this, and the franchisee (or franchisor) has officially filed a previous application for early termination of the agreement. Only significant breach of the terms of a franchising agreement is a ground for its termination without notice. Reasons for bringing the franchising agreement to an early termination without prior notice may be, for example, refusal to make a payment for the right to use a franchise or repeated violation of the main rules established for a franchise network (for example, a ban on cooperation with competitors). Determining whether there is a reason to terminate the contract is sufficient requires a comprehensive assessment of the circumstances of each individual case, as well as the interests of the franchisor 
and franchisee. The termination of the contract must take place within a reasonable period of time from the moment the circumstances arise, which has led to a contradiction between the parties.

It should be noted that according to the German law on standard business terms and conditions, the provision on "sufficient ground" applies to all franchising agreements without exception, even if it is not specified in the agreement itself. The same applies to the need to send an official notice before terminating a franchise agreement without prior reference. After the termination of the franchise agreement, the franchisee has the right to demand compensation for the income that he could obtain in the further implementation of franchising activities. If his claim is satisfied, the reimbursement may be equal to the average annual income over the past five years of activity. No reimbursement will be awarded if the agreement was cancelled by the franchisee itself or in the event of termination of the contract without prior notice over violation of rules of conduct by the latter (Metzlaff, Billing, 2011).

Survival of the franchising agreement may be made solely by mutual consent of the parties. For this reason, the franchisor may refuse to renew the contract without substantiating his decision. However, it should be noted that the franchiser's freedom of choice is limited to a claim for damages. So, if the franchisor expressed his intention to extend the franchise agreement and thus prompted the franchisee to invest in updating the equipment necessary for doing business on the eve of the expiration of the agreement, and then refused to renew agreement, then the franchisee had enough grounds to apply to the court with a claim for damages.

\section{Conclusion}

On the basis of the above, we conclude that Germany has formed a franchising market with a large number of local franchising companies in more than 42 different areas: from retail, fast food establishments, hotels, education, car rental, and provision of domestic services to energy, health care, and telecommunications.

There is no single law on franchising in this country. Since the provisions governing the issues of franchising in general and the franchising agreement in particular are in the German Civil Code, the German Commercial Code, in a competitive, case law, antimonopoly legislation, as well as in European and international legal acts, it can be concluded that the franchising agreement in Germany belongs to the category of mixed contracts.

The franchisor and the franchisee are subject to the principle of culpa in contrahendo on the disclosure of information at the stage of negotiations on concluding a franchising agreement, during which the parties must provide true data, not mislead each other, and not make false promises. As a result of the violation of this principle, guilty persons may be brought to civil liability and are obliged to reimburse for damages.

In accordance with German civil law, the parties are free to determine the terms of the franchising agreement and may set them at their own discretion, but taking into account the general principles provided for by the Civil Code and the rules established in the anti-monopoly legislation. The recommended list of provisions to be included in the agreement is provided for in the European Code of Ethics for Franchising, which is applied in Germany for the regulation of issues related to this institution. Also, this act contains additional requirements for the parties to the franchising agreement and the key principles of their activities.

The maximum and minimum terms of the franchise agreement in the country under consideration are not provided, but usually, it is concluded for 10 years the period for which the franchisee can recover the funds spent on the purchase of a franchise.

A franchising agreement may be terminated due to the expiration of the term, its invalidation or upon a mutual agreement of the parties.

\section{References:}

Marzheuser-Wood, B. (2014). The Franchise Law Review. Germany. Law Business Research Ltd. London.

Statistiken zum Thema Franchise. Retrieved from: https://de.statista.com/themen/1166/franchise/

European Code of Ethics for franchising. Retrieved from: http://www.eff-franchise.com/Data/EFF\%20Code\%20 of\%20Ethics\%20for\%20Franchising\%20-\%20FINAL\%2007122016.pdf

Metzlaff, K., Billing, T. (2011). Franchise in 32 jurisdictions worldwide. Germany. Law Business Research Ltd.

Bürgerliches Gesetzbuch (BGB) in der Fassung der Bekanntmachung vom 2. Januar 2002. Retrieved from: http://www.gesetze-im-internet.de/bgb/BJNR001950896.html

Franchise 2019. Germany. Retrieved from: https://iclg.com/practice-areas/franchise-laws-andregulations/ germany\#chaptercontent 2

Unfair Contract Terms Act 1977. Retrieved from: https://www.legislation.gov.uk/ukpga/1977/50

Treaty on the Functioning of the European Union. Retrieved from: http://www.lisbon-treaty.org/wcm/the-lisbontreaty/treaty-on-the-functioning-of-the-european-union-and-comments.html/

Commission Regulation (EU) № 330/2010 of 20 April 2010 on the application of Article 101 (3) of the Treaty on the Functioning of the European Union to the vertical agreements and concerted practices categories. Retrieved from: https:// eur-lex.europa.eu/legal-content/EN/ALL/?uri=CELEX\%3A32010R0330 